\title{
Evaluation of the Effect of Elevated Temperatures on Compressive Strength of Recycled Aggregate Concrete
}

\author{
Arif Cekic ${ }^{1 *}$, Bulent Celik ${ }^{2}$ and Jale Tezcan ${ }^{3}$ \\ ${ }^{1}$ Intertek-PSI, Farmington Hills, United States \\ ${ }^{2}$ Department of Civil Engineering, Nisantasi University, Turkey \\ ${ }^{3}$ Department of Civil and Environmental Engineering, Southern Illinois University, United States
}

Submission: March 13, 2018; Published: May 25, 2018

*Corresponding author: Arif Cekic, Intertek-PSI, 37483 Interchange Drive, Farmington Hills, Michigan, USA, Tel: 734-564-3562;

Email: arif.cekic@psiusa.com.

\begin{abstract}
Recycled concrete aggregates are produced from demolition of concrete structures. Their successful integration to aggregate supply chain may play an essential role in creating a sustainable infrastructure system. With increasing acceptance of the recycled aggregates as a main concrete ingredient, a need has emerged to quantify the engineering properties of recycled aggregate concrete. A significant body of research exists regarding the comparison of the mechanical properties of the recycled aggregate concrete to those of natural aggregate concrete. While recent research efforts have addressed the effect of mix design on various engineering properties, the effect of exposure to elevated temperatures has not been sufficiently investigated, despite the fact that a variety of concrete structures are exposed to high temperatures either as part of their operation or due to unexpected events such as thermal shock or fire. This article uses experimental results from 31 compressive strength tests to investigate the effect of exposure to elevated temperatures on the compressive strength of natural and recycled aggregate concrete for different levels of water-to-cement ratio, maturity (i.e. age), and recycled aggregate replacement ratio. The findings of this study are relevant to the design, operation and maintenance of a variety of structures that are regularly exposed to elevated temperatures during their life cycle, such as concrete chimneys, furnaces, reactor vessels and coal gasification vessels.
\end{abstract}

Keywords:Recycled aggregate; Water-to-cement ratio; Replacement ratio; Maturity; Exposure temperatures; Compressive strength.

\section{Introduction}

Waste materials and industrial by products have been utilized in construction industry, mainly due to economic and environmental concerns. Various waste materials and industrial byproducts such as fly ash and silica fume [1], waste tire [2-4], waste glass [5-6], and waste plastic [7-9] have been introduced to Portland cement concrete mixes over the last few decades.

Utilization of construction waste materials as an aggregate source for production of new Portland cement concrete has become more attractive in the recent decade due to drastic increase in landfill costs, concerns over scarcity of natural resources for aggregate, and environmental concerns. In this regard, demolished concrete or recycled concrete aggregate is also classified as solid waste and has found an increased use in Portland concrete production [10,11]. Recycled concrete aggregate, also referred to as recycled crushed concrete, is typically produced via demolition of Portland cement concrete elements of buildings, roads, and other structures made of
Portland cement concrete [12]. In general, use of aggregates from demolished concrete structures is considered for two reasons: creating a sustainable alternative to storage of demolished concrete and preservation of limited natural resources [13]. Rubble generated through demolition of foundations and concrete building elements as well as concrete roadways and airport runways has been successfully integrated into the aggregate supply chain around the world. Recycled aggregates have become a part of various construction projects as new concrete, base and subbase aggregates or structural backfill materials [14].

Since 1970s, many researchers have focused on the evaluation of the engineering properties of recycled aggregates in an effort to identify the design requirements for their utilization in new concrete. An early review of the use of recycled concrete as an aggregate was provided by Nixon [15]. A more comprehensive document encompassing research performed by 


\section{Civil Engineering Research Journal}

various institutions between 1945 to 1985 has been compiled by Hansen [16]. RILEM Committee 121-DRG has published specifications [17] for concrete with recycled aggregates. Ross [18] summarized the general applications of the recycled aggregates in various countries, emphasizing the application type, allowable recycle materials by volume, recycled sand content, allowable concrete class and allowable limits of other materials by mass in percent.

The use of recycled aggregates is known to affect the mechanical properties of concrete. In particular, recycled aggregate concretes tend to exhibit lower strength and stiffness relative to their natural aggregate counterparts [1928]. Limbachiya et al. [20] found that inclusion of up to $30 \%$ coarse recycled concrete aggregate (RCA) did not impact the ceiling strength of high strength concrete (C50 or higher) while a gradual reduction in strength was observed at higher replacement ratios. Using an experimental database, Xiao et al. [22] investigated the potential relationships among the flexural strength, the compressive strength, the splitting tensile strength, the density, and the elastic modulus. Their research identified marked differences between the interrelationships among various mechanical properties of recycled aggregate concrete and those of natural aggregate concrete. Etxeberria et al. [23] investigated that effect of the replacement ratio of recycled aggregates on the shear strength of the concrete beams. They found that the use of recycled aggregates up to a replacement ratio of 25 percent had no appreciable effect on the shear strength. At higher replacement ratios, a linear decrease in shear strength was observed. Kwan et al. [30] concluded that proposed design strength of the concrete can be achieved with a recycled concrete aggregate replacement ratio of up to $80 \%$. Yildirim et al. [29] suggest that the water-to-cement ratio, the degree of saturation (i.e. absorption) and the replacement ratio are negatively associated with the compressive strength of recycled aggregate concrete. Cakir [31] investigated that effect of inclusion of granulated blast furnace slag and silica fume in recycled aggregate concrete on its tensile splitting strength and the compressive strength. A reduction of approximately $24 \%$ in the compressive strength at a replacement ratio of $100 \%$ was observed. Tensile splitting strength was notable at $50 \%$ plus recycled aggregate content. Test specimens incorporating granulated blast furnace slag were observed to have a greater tensile-to-compressive strength ratio than the ones incorporating silica fume.

Despite extensive research, many questions remain regarding the factors affecting the compressive strength of recycled aggregate concrete. Silva et al. [25,27] provide a systematic review of publications between 1977 to 2014 addressing the effect of data from published studies. Silva et al. [25] point out significant discrepancies in the literature, attributing the lack of consensus to two main reasons:

a. The difficulty of considering all the variables affecting compressive strength including but not limited to the replacement ratio, size, quality, and moisture content of the recycled aggregates, mix design, maturity, and environmental conditions;

b. The difficulty of isolating the effect of single factor on the compressive strength of concrete, due to dependence of the relationship on the values of the remaining variables, and in some cases, on the value of the considered variable itself. This difficulty precludes describing the effect of a variable on the compressive strength of concrete in terms of a linear relationship. It is clear that further research is needed to fully understand the strength development in recycled aggregate concrete.

This article uses the experimental results from 31 compressive strength tests, each test result being the average of three specimens, to investigate how the compressive strength of recycled aggregate is affected by exposure to elevated temperatures, for different levels of water-to-cement ratio, replacement ratio, and concrete maturity (i.e. age). Knowledge on the effect of elevated temperatures on the compressive strength is relevant in the design, operation and maintenance of a variety of structures that are regularly exposed to elevated temperatures during their life cycle, such as concrete chimneys, furnaces, reactor vessels and coal gasification vessels. The findings of this paper are also relevant in predicting the response of structures made with recycled aggregate concrete in the event of a thermal shock or fire.

The rest of this article has been organized as follows: Section 2 describes the concrete mix design. Section 3 explains the experimental program. Section 4 presents the test results and discussion. The article ends with the conclusions in Section 5.

\section{Concrete Mix Design}

In the production of concrete, ASTM Type I Portland cement (PC 42.5) was used as binder material. The chemical composition of the Portland cement is provided in Table 1.

Table 1: Chemical composition of Portland cement.

\begin{tabular}{|c|c|}
\hline Analysis Report & Portland Cement (Weight Percentage) \\
\hline $\mathrm{SiO}_{2}$ & 20.64 \\
\hline $\mathrm{AlOO}_{3}$ & 5.06 \\
\hline $\mathrm{Fe}_{2} \mathrm{O}_{3}$ & 3.14 \\
\hline $\mathrm{CaO}$ & 63.98 \\
\hline $\mathrm{MgO}$ & 0.95 \\
\hline $\mathrm{SO}_{3}$ & 2.71 \\
\hline $\mathrm{Na}_{2} \mathrm{O}$ & 0.31 \\
\hline $\mathrm{K}_{2} \mathrm{O}$ & 0.8 \\
\hline Insoluble Residue & 0.29 \\
\hline Loss of Ignition & 1.39 \\
\hline Free Lime & 1.41 \\
\hline
\end{tabular}




\section{Civil Engineering Research Journal}

\begin{tabular}{|c|c|}
\hline $\mathrm{C}_{3} \mathrm{~S}$ & 52.52 \\
\hline $\mathrm{C}_{2} \mathrm{~S}$ & 19.64 \\
\hline $\mathrm{C}_{3} \mathrm{~A}$ & 8.1 \\
\hline $\mathrm{C}_{4} \mathrm{AF}$ & 9.56 \\
\hline
\end{tabular}

Natural coarse aggregates were the crushed limestone No. I and No. II with blue-gray color. Natural fine aggregates were the natural sand, and crushed limestone sand (No. 0). The recycled aggregates were produced from the concrete produced in a laboratory environment. The physical properties and gradation of the natural coarse and fine aggregates and recycled aggregates in Table 2.

Table 2: Gradation and physical properties of the natural and recycled aggregates.

\begin{tabular}{|c|c|c|c|c|c|c|}
\hline \multirow{2}{*}{ Sieve size $(\mathrm{mm})$} & \multirow{2}{*}{ Sand (\% Passing) } & \multirow{2}{*}{$\begin{array}{c}\text { Crushed Sand (\% } \\
\text { Passing) }\end{array}$} & \multirow{2}{*}{$\begin{array}{l}\text { Recycled Coarse } \\
\text { Aggregate (4- } \\
8 \mathrm{~mm})\end{array}$} & \multirow{2}{*}{$\begin{array}{l}\text { Recycled Coarse } \\
\text { Aggregate (8- } \\
\text { 16mm) }\end{array}$} & \multicolumn{2}{|c|}{$\begin{array}{c}\text { Crushed Limestone (Blue-Gray) (\% } \\
\text { Passing) }\end{array}$} \\
\hline & & & & & No. I & No. II \\
\hline 16 & 100 & 100 & 100 & 100 & 100 & 100 \\
\hline 8 & 100 & 100 & 100 & 0 & 56.5 & 2.1 \\
\hline 4 & 100 & 100 & 0 & 0 & 3.7 & 0.1 \\
\hline 2 & 99.8 & 66.6 & 0 & 0 & 0.2 & 0 \\
\hline 1 & 99.3 & 38.2 & 0 & 0 & 0 & 0 \\
\hline 0.5 & 97.2 & 20.3 & 0 & 0 & 0 & 0 \\
\hline 0.25 & 11.8 & 10.3 & 0 & 0 & 0 & 0 \\
\hline 0.125 & 0.6 & 3 & 0 & 0 & 0 & 0 \\
\hline Fineness modulus & 1.91 & 3.62 & 5 & 6 & 6.4 & 6.98 \\
\hline Absorption (\%) & 2.77 & 2.96 & 7.65 & 7.16 & 2.16 & 2.06 \\
\hline $\begin{array}{l}\text { Moisture content } \\
(\%)\end{array}$ & 0.8 & 0.5 & 4.77 & 3.09 & 0.6 & 0.5 \\
\hline $\begin{array}{l}\text { Specific gravity } \\
\text { (dry) }\end{array}$ & 2.36 & 2.34 & 2.19 & 2.22 & 2.6 & 2.51 \\
\hline Specific gravity & \multirow[b]{2}{*}{2.43} & \multirow[b]{2}{*}{2.41} & \multirow[b]{2}{*}{2.35} & \multirow[b]{2}{*}{2.38} & \multirow[b]{2}{*}{2.66} & \multirow[b]{2}{*}{2.56} \\
\hline $\begin{array}{l}\text { (saturated surface } \\
\text { dry) }\end{array}$ & & & & & & \\
\hline $\begin{array}{l}\text { Specific gravity } \\
\text { (apparent) }\end{array}$ & 2.53 & 2.52 & 2.63 & 2.64 & 2.75 & 2.64 \\
\hline
\end{tabular}

A chemical admixture (ADVA Flow 400) was used in concrete mixes as water reducing agent. The physical and chemical properties of the water reducing agent are provided in Table 3. A coloring agent, organic-base red powder, was used in the recycled aggregate concrete batches in order to be able to distinguish the new and old mortar. Per manufacturer's specifications, the coloring agent was introduced to the concrete batch by approximately 3 percent of weight of cement.

Table 3: Physical and chemical properties of water-reducing agent.

\begin{tabular}{|c|c|}
\hline Color & Dark Yellow-Light Brown \\
\hline Physical state & Liquid \\
\hline $\mathrm{pH}$ value & $5.8 \pm 1$ \\
\hline Freezing point & $-3^{\circ} \mathrm{C}$ \\
\hline Specific gravity & $1.05 \mathrm{~g} / \mathrm{cm}^{3}$ \\
\hline Chloride content & $0.0 \%$ \\
\hline
\end{tabular}

\section{Experimental Study}

An experimental study was designed to investigate the individual and combined effects of the following four variables on compressive strength of recycled aggregate concretes: exposure to temperature, water/cement ratio, replacement ratio of recycled coarse aggregate, and maturity (i.e. age).

A total of 31 tests were conducted using the levels of the variables noted in Table 4. Each test consisted of measuring the compressive strength of three hardened cylinder specimens of $100 \mathrm{~mm}$ by $200 \mathrm{~mm}$, in accordance with ASTM C39. The specimens were heated in an electric furnace up to temperatures of 105,175 and $250{ }^{\circ} \mathrm{C}$. Each peak temperature was maintained for three hours to achieve the thermal steady state. At the end of three hours, the power was turned off and the specimens were kept in the furnace until the furnace cooled down to room temperature. The temperatures were recorded at every 30 minutes. The specimens were tested at room temperature and after the heating and cooling cycle. Of the 31 tests, 15 tests were performed at 28 days, and the rest at 90 days.

\section{Results and Discussion}

Table 5 shows the compressive strength measurements for the 31 tests, the associated variables of which are listed in Table 4. The result of each test is determined as the average of three specimens. 


\section{Civil Engineering Research Journal}

Table 4: Test variables.

\begin{tabular}{|c|c|c|c|c|}
\hline \multirow{2}{*}{ Test } & \multicolumn{4}{|c|}{ Test Variables } \\
\hline & $\mathbf{w} / \mathrm{C}$ & Replacement Ratio (\%) & Temperature $\left({ }^{\circ} \mathrm{C}\right)$ & Age (days) \\
\hline 1 & 0.35 & 0 & 22 & 90 \\
\hline 2 & 0.35 & 0 & 105 & 28 \\
\hline 3 & 0.35 & 0 & 105 & 28 \\
\hline 4 & 0.35 & 0 & 175 & 28 \\
\hline 5 & 0.35 & 0 & 250 & 28 \\
\hline 6 & 0.35 & 50 & 22 & 28 \\
\hline 7 & 0.35 & 50 & 105 & 90 \\
\hline 8 & 0.35 & 100 & 22 & 90 \\
\hline 9 & 0.35 & 100 & 105 & 28 \\
\hline 10 & 0.35 & 100 & 175 & 90 \\
\hline 11 & 0.35 & 100 & 250 & 90 \\
\hline 12 & 0.4125 & 25 & 250 & 90 \\
\hline 13 & 0.475 & 0 & 175 & 90 \\
\hline 14 & 0.475 & 0 & 175 & 90 \\
\hline 15 & 0.475 & 25 & 22 & 28 \\
\hline 16 & 0.475 & 50 & 250 & 28 \\
\hline 17 & 0.475 & 100 & 105 & 90 \\
\hline 18 & 0.475 & 100 & 175 & 28 \\
\hline 19 & 0.5375 & 25 & 175 & 28 \\
\hline 20 & 0.5375 & 50 & 22 & 90 \\
\hline 21 & 0.5375 & 75 & 250 & 90 \\
\hline 22 & 0.6 & 0 & 22 & 28 \\
\hline 23 & 0.6 & 0 & 105 & 90 \\
\hline 24 & 0.6 & 0 & 105 & 90 \\
\hline 25 & 0.6 & 0 & 250 & 90 \\
\hline 26 & 0.6 & 50 & 105 & 28 \\
\hline 27 & 0.6 & 50 & 105 & 28 \\
\hline 28 & 0.6 & 100 & 22 & 28 \\
\hline 29 & 0.6 & 100 & 175 & 90 \\
\hline 30 & 0.6 & 100 & 175 & 90 \\
\hline 31 & 0.6 & 100 & 250 & 28 \\
\hline
\end{tabular}

Table 5: Test results, $\mathrm{f}_{\mathrm{c} 1}, \mathrm{f}_{\mathrm{c} 2}, \mathrm{f}_{\mathrm{c} 3}$ compressive strength of the three specimens, $\overline{f_{c}}:$ mean strength.

\begin{tabular}{|c|c|c|c|c|}
\hline Test & fc1 (MPa) & $\mathbf{f c 2}(\mathbf{M P a})$ & $\mathbf{f c 3}(\mathbf{M P a})$ & $\overline{f_{c}} \mathbf{( M P a )}$ \\
\hline 1 & 39.3 & 45.3 & 35.6 & 30 \\
\hline 2 & 39.7 & 31.8 & 30 & 29.9 \\
\hline 3 & 31.9 & 29.3 & 47 & 44.8 \\
\hline 4 & 50.5 & 36.8 & 57 & 52.2 \\
\hline 5 & 50.5 & 49.1 & 41.1 & 37.7 \\
\hline 6 & 34 & 38 & 36.6 & 39.3 \\
\hline 7 & 41.7 & 39.6 & 36.9 & 40 \\
\hline 10 & 44.4 & 38.8 & 33.1 & 37.2 \\
\hline
\end{tabular}




\section{Civil Engineering Research Journal}

\begin{tabular}{|c|c|c|c|c|}
\hline 11 & 37.8 & 45.2 & 45.2 & 42.7 \\
\hline 12 & 46.9 & 39.7 & 48.1 & 34.9 \\
\hline 13 & 32.8 & 36.7 & 34.1 & 32.8 \\
\hline 14 & 32.4 & 33.8 & 31.6 & 32.2 \\
\hline 15 & 32.7 & 32.4 & 36.2 & 38.7 \\
\hline 16 & 42.3 & 37.5 & 27.2 & 30.7 \\
\hline 17 & 31.8 & 33.1 & 34.9 & 32 \\
\hline 18 & 32.6 & 28.5 & 29.1 & 31.3 \\
\hline 19 & 26 & 28 & 33.1 & 33.3 \\
\hline 20 & 30.4 & 33.3 & 20.6 & 22.9 \\
\hline 22 & 33 & 33.8 & 23.3 & 24.8 \\
\hline 23 & 25.4 & 22.7 & 25.8 & 23 \\
\hline 24 & 25.4 & 25.6 & 32.2 & 32.5 \\
\hline 26 & 21.2 & 22.2 & 20.9 & 23.1 \\
\hline 27 & 29.7 & 35.7 & 25.6 & 25.5 \\
\hline 29 & 23.5 & 24.9 & 24 & 26.3 \\
\hline 31 & 26.7 & 24.3 & 28.9 & 28.4 \\
\hline
\end{tabular}
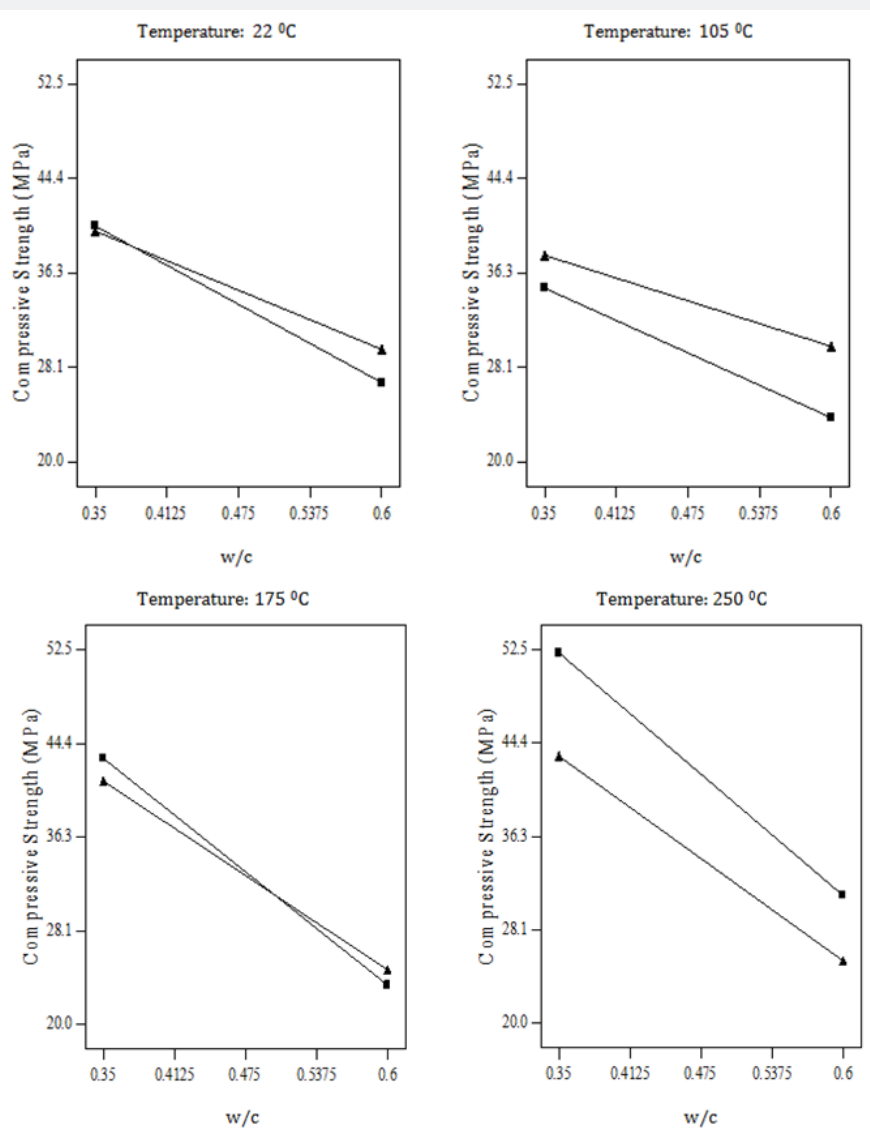

Replacement Ratio $\quad \mathbf{0} \% \quad \Delta \quad 100 \%$

Figure 1: 28-day compressive strength for different w/c, replacement ratio, and exposure temperatures 


\section{Civil Engineering Research Journal}
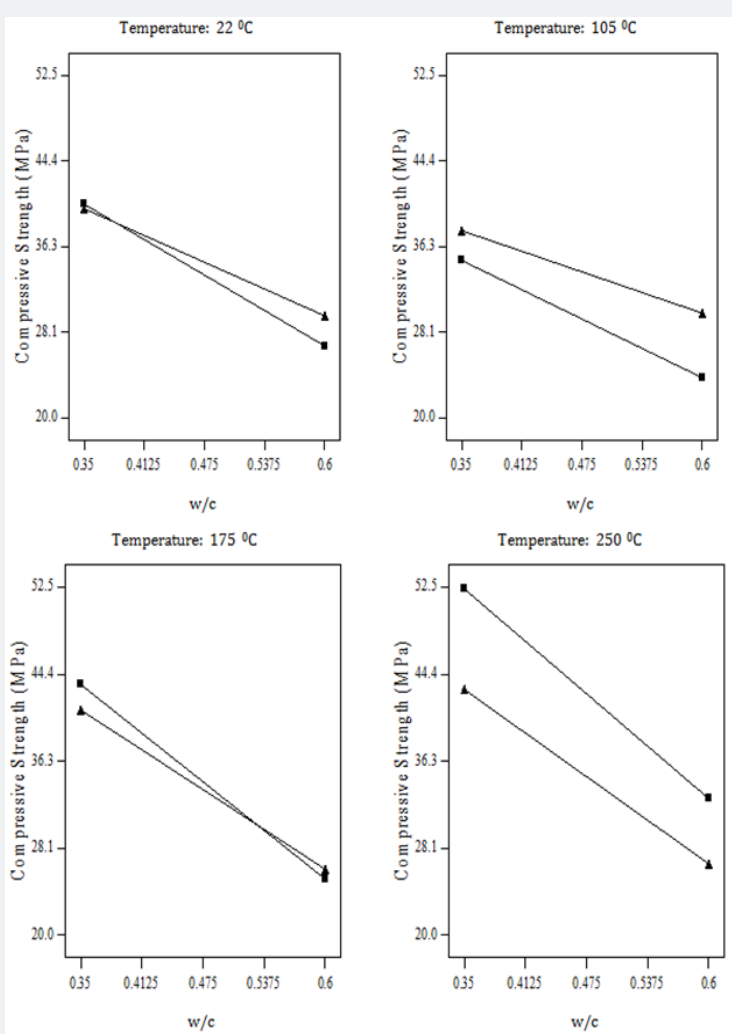

Replacement Ratio $\quad$ 0\% $\quad \mathbf{\Delta 1 0 0 \%}$

Figure 2: 28-day compressive strength for different w/c, replacement ratio, and exposure temperatures
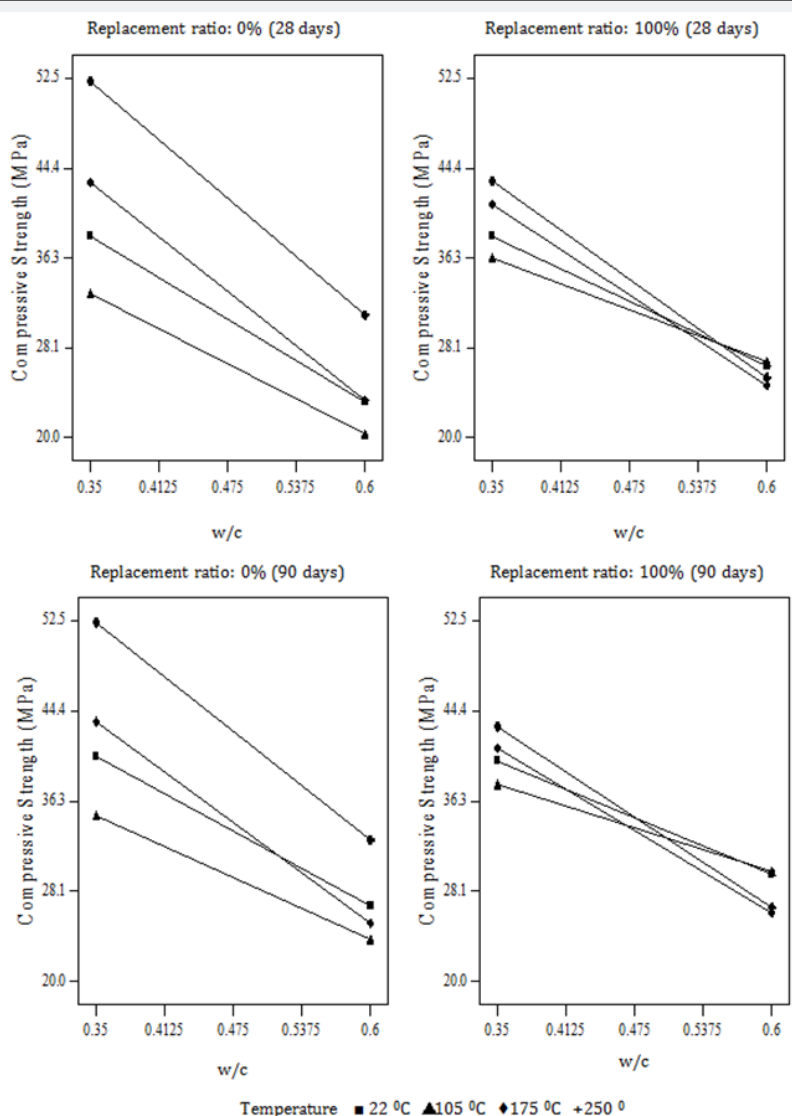

Figure 3: Variation of compressive strength with w/c and exposure temperatures 


\section{Civil Engineering Research Journal}
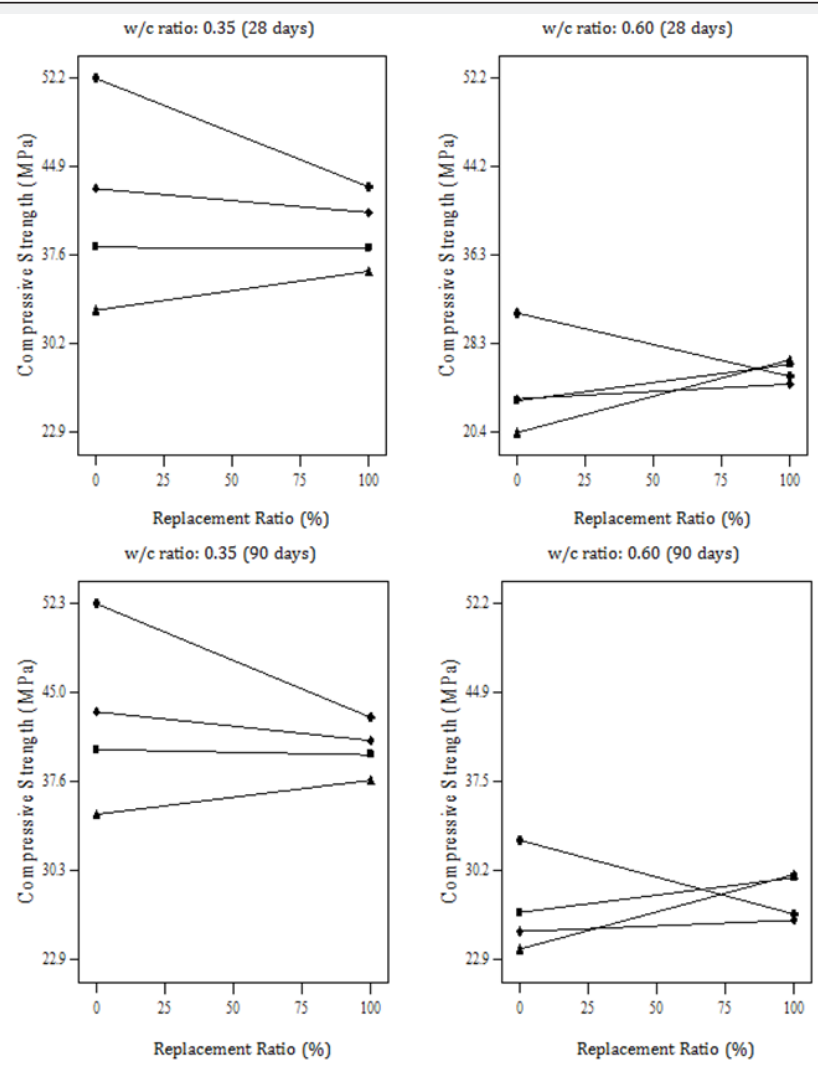

Temperature $\cdot 22^{\circ} \mathrm{C} \Delta 105^{\circ} \mathrm{C} \cdot 175^{\circ} \mathrm{C}+250^{\circ} \mathrm{C}$

Figure 4: Variation of compressive strength with replacement ratio and exposure temperatures
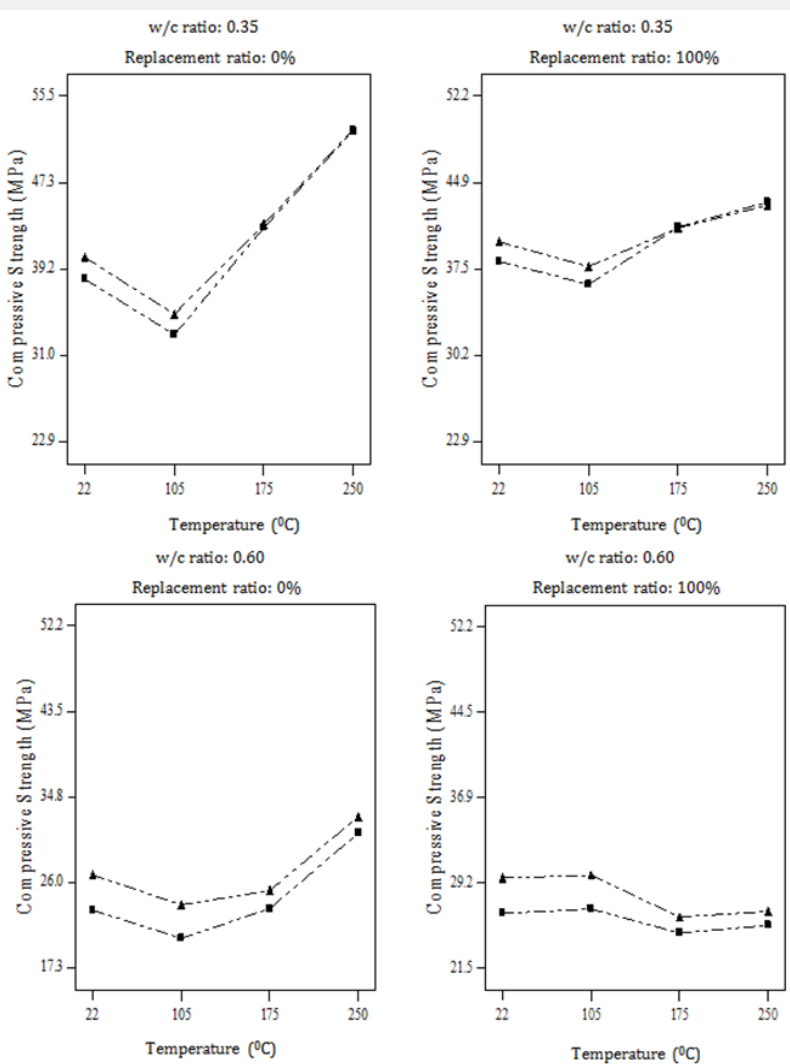

Age 28 days $\mathbf{\Lambda} 90$ days

Figure 5: Variation of compressive strength with exposure temperature, replacement ratio, and age. 


\section{Civil Engineering Research Journal}

Figures 1 through 5 show the variation of mean compressive strength with respect to the test variables. The 28-day and 90day mean compressive strength for different water-to-cement ratio, replacement ratio, and exposure temperature are shown in Figures 1 \& 2, respectively.

Based on the experimental results, the following observations are noted regarding the effect of the four variables on the compressive strength.

Each temperature interval (i.e. $22^{\circ} \mathrm{C}$ and $105^{\circ} \mathrm{C}, 105^{\circ} \mathrm{C}$ to $175^{\circ} \mathrm{C}$, and $175^{\circ} \mathrm{C}$ to $250^{\circ} \mathrm{C}$ ) showed a different pattern in terms of a change in compressive strength. From $22{ }^{\circ} \mathrm{C}$ to $105{ }^{\circ} \mathrm{C}$, the use of recycled aggregate appears to be associated with a modest increase (up to \%14) in the compressive strength.

Considerable difference in compressive strength was observed between natural and recycled aggregate concretes exposed to a temperature of $250{ }^{\circ} \mathrm{C}$. For exposure temperature $250{ }^{\circ} \mathrm{C}$, the compressive strength of recycled aggregate concrete is 21 to $23 \%$ lower than natural aggregate concrete.

Compressive strength of recycled aggregate concrete exposed to $175{ }^{\circ} \mathrm{C}$ is slightly lower (up to $5 \%$ ) than that of natural aggregate concrete when the $\mathrm{w} / \mathrm{c}$ ratio is 0.35 . However, with $\mathrm{w} / \mathrm{c}$ equal to 0.6 , the opposite is observed.

For the natural aggregate concretes, generally a slight decrease in the compressive strength, relative to the compressive strength determined at $22{ }^{\circ} \mathrm{C}$, was observed when the exposure temperature was increased to $105{ }^{\circ} \mathrm{C}$. As the exposure temperature was increased to $175^{\circ} \mathrm{C}$, the concrete compressive strength showed a trend to recover the loss in strength to the strength levels that were observed at $22{ }^{\circ} \mathrm{C}$. As the exposure temperature was further increased to $250^{\circ} \mathrm{C}$, a gradual increase in the compressive strength from the strength levels at $175{ }^{\circ} \mathrm{C}$ was also observed. However, for the recycled aggregate concrete, a general trend in compressive strength increase or decrease was not observed with varying exposure temperature levels. The test results also indicated that in general, compressive strength of recycled aggregate concrete was relatively insensitive to the change in exposure temperature compared to that of the natural aggregate concrete.

As expected, compressive strength of both natural and recycled aggregate concrete increased with age (up to 90 days). The highest level of increase of compressive strength with age was observed for natural aggregate concrete with a watercement ratio of 0.60 and an exposure temperature of $105^{\circ} \mathrm{C}$.

The incorporation of recycled aggregate into concrete mixes affect the compressive strength of concretes. Compressive strengths of recycled and natural aggregate concrete ranged from $25 \mathrm{MPa}$ to $43 \mathrm{MPa}$ and $20 \mathrm{MPa}$ to $52 \mathrm{MPa}$, respectively. The change in the upper and lower values of compressive strength can be attributed to the change in the water-cement ratio, exposure temperature and maturity of the specimens.
The 28-day compressive strength of natural aggregate concretes increased by $62-84 \%$ when the water-cement ratio was reduced from 0.60 to 0.35 . On the other hand, the recycled aggregate concrete showed an increase of $35-70 \%$ in the 28-day compressive strength for the same change in the water-cement ratio. These findings indicate that the compressive strength of natural aggregate concrete is more sensitive that recycled aggregate concrete to the changes in water-to-cement ratio.

\section{Conclusion}

Based on the compressive strength test results and findings noted above, the following conclusions can be drawn:

a. The incorporation of recycled aggregate into concrete mixes changes the compressive strength of concrete. The amount and direction of change is dependent on watercement ratio, exposed temperature, replacement ratio, and maturity.

b. A considerable difference in compressive strength is observed between natural and recycled aggregate concretes exposed to a temperature of $250{ }^{\circ} \mathrm{C}$.

c. Although the exposure temperature has an apparent effect on the compressive strength, a general trend in terms of an increase or decrease in compressive strength of recycled concrete aggregates, with varying exposure temperature levels, was not noted.

d. Compressive strength of the recycled aggregate concrete appears to be less sensitive to changes in exposure temperatures than natural aggregate concrete. A similar observation can be made regarding water-to-cement ratio.

It must be noted that the effect of elevated temperatures over $250{ }^{\circ} \mathrm{C}$ on the compressive strength was outside the scope of this paper. In addition to the impact of temperatures exceeding 250 ${ }^{\circ} \mathrm{C}$, potential impact of the heating and cooling rate, duration of maximum exposure temperature to the concrete compressive strength need to be investigated for a more complete assessment of the effect of exposure to elevated temperatures on the compressive strength of recycled aggregate concrete.

\section{References}

1. Celik B (2001) Effect of binding material composition on bond strength of concrete subjected to different exposure conditions. MS Thesis, Bogaziçi University, Istanbul, Turkey.

2. Guneyisi E, Gesoglu M, Ozturan T (2004) Properties of rubberized concretes containing silica fume. Cement and Concrete Research 34(12): 2309-2317.

3. Papakonstantinou CG, Tobolski MJ (2006) Use of waste tire steel beads in Portland cement concrete. Cement and Concrete Research 36(9): 1686-1691.

4. Hernandez-Olivares F, Barluenga G, Bollati M, Witoszek B (2002) Static and dynamic behaviour of recycled tyre rubber-filled concrete. Cement and Concrete Research 32(10): 1587-1596.

5. Shayan A, Xu A (2004) Value-added utilization of waste glass in concrete. Cement and Concrete Research 34(1): 81-89. 


\section{Civil Engineering Research Journal}

6. Park SB, Lee BC, Kim JH (2004) Studies on mechanical properties of concrete containing waste glass aggregate. Cement and Concrete Research 34(12): 2181-2189.

7. Soroushian P, Plasencia J, Ravanbakhsh S (2003) Assessment of reinforcing effects of recycled plastic and paper in concrete. ACI Materials Journal 100(3): 203-207.

8. Silva DA, Betioli AM, Gleize PJP, Roman HR, Gomez LA, Ribeiro JLD (2005) Degradation of recycled PET fibers in Portland cement-based materials. Cement and Concrete Research 35(9): 1741-1746.

9. Palos A, D’Souza NA, Snively CT, Reidy III RF (2001) Modification of cement mortar with recycled ABS. Cement and Concrete Research 31(7): 1003-1007.

10. Henrichsen A (2000) Use of recycled aggregates in Europe. Proceedings of international seminar on recycled concrete, Niigata-Japan 29: 1-8.

11. Katz A (2003) Properties of concrete made with recycled aggregate from partially hydrated old concrete. Cement and Concrete Research 33(5): 703-711

12. Lin YH, Tyan YY, Chang TP, Chang CY (2004) An assessment of optimal mixture for concrete made with recycled concrete aggregates. Cement and Concrete Research 34(8): 1373-1380.

13. Ajdukiewicz A, Kliszczewicz A(2002) Influence of recycled aggregates on mechanical properties of HS/HPC. Cement and Concrete Composites 24(2): 269-279.

14. Lam L, Poon CS, Kou SC (2002) Use of recycled aggregates in molded concrete bricks and blocks. Construction and Building Materials 16(5): 281-289.

15. Nixon PJ (1978) Recycled concrete as an aggregate for concrete - a review. Materials and Structures 11(65): 371-378.

16. Hansen TC (1986) Recycled aggregates and recycled aggregate concrete second state-of-the art report developments 1945-1985. Materials and Structures 19(3): 201-246.

17. RILEM 121 DRG (1994) Specifications for concrete with recycled aggregates. Materials and Structures 27(9): 557-559.

18. Roos F (2002) Ein Beitrag zur bemessung von beton mit zuschlag aus rezyklierter gesteinskörnung nach DIN 1045-1.

19. Chan C (1998) Recycled aggregate in shotcrete and concrete. Master of Applied Science Thesis. University of British Columbia.

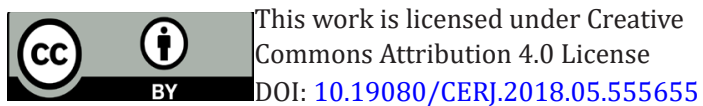

20. Limbachiya MC, Leelawat T, and Dhir RK (2000) Use of recycled concrete aggregate in high-strength concrete. Materials and Structures 33(9): 574-580

21. Tamura H, Nishio A, Ohashi J, Imamoto K (2001) High quality recycled aggregate concrete (HiRAC) processed by decompression and rapid release. Fifth international conference on recent advances in concrete technology (ACI Special Publication) 200: 491-502.

22. Xiao JZ, Li JB, Zhang C (2006) On relationships between the mechanical properties of recycled aggregate concrete: an overview. Materials and Structures 39(6): 655-664

23. Etxeberria M, Mari AR, Vazquez E (2007) Recycled aggregate concrete as structural material. Materials and Structures 40(5): 529-541.

24. McNeil K, Kang THK (2013) Recycled concrete aggregates: a review. International Journal of Concrete Structures and Materials 7(1): 61-69.

25. Silva RV, de Brito J, Dhir RK (2014) Properties and composition of recycled aggregates from construction and demolition waste suitable for concrete production. Construction and Building Materials 65: 201207.

26. Bravo M, de Brito J, Pontes J, Avengalista L (2015) Mechanical performance of concrete made with aggregates from construction and demolition waste recycling plants. Journal of Cleaner Production 99: 59-74.

27. Silva VS, de Brito J, Dhir RK (2016) Establishing a relationship between modulus of elasticity and compressive strength of recycled concrete aggregate. Journal of Cleaner Production 112(4): 2171-2186.

28. Medina C, Zhu W, Howind T, Sanchez de Rojas MI, Frias M (2014) Influence of mixed recycled aggregate on the physical- mechanical properties of recycled concrete. Journal of Cleaner Production 68: 216-225.

29. Yildirim ST, Meyer C, Herfeliner S (2015) Effects of internal curing on the strength, drying shrinkage and freeze-thaw resistance of concrete containing recycled concrete aggregates. Construction and Building Materials 91: 288-296.

30. Kwan WH, Ramli M, Kam JK, Sulieman MZ (2012) Influence of the amount of recycled coarse aggregate in concrete design and durability properties. Construction and Building Materials 26(1): 565-573.

31. Cakir O (2014) Experimental analysis of properties of recycled aggregate (RCA) concrete with mineral additives. Construction and Building Materials 68:17-25.

\section{Your next submission with Juniper Publishers will reach you the below assets}

- Quality Editorial service

- Swift Peer Review

- Reprints availability

- E-prints Service

- Manuscript Podcast for convenient understanding

- Global attainment for your research

- Manuscript accessibility in different formats

( Pdf, E-pub, Full Text, Audio)

- Unceasing customer service

Track the below URL for one-step submission https://juniperpublishers.com/online-submission.php 